\title{
35. PYROLYTIC ASSAY OF SAMPLES FROM SITE 799 ${ }^{1}$
}

\author{
Barry J. Katz ${ }^{2}$
}

\begin{abstract}
Pyrolysis techniques were used to characterize the organic matter contained within the penetrated section and to assess the presence of heavy hydrocarbon shows. The Rock-Eval data indicate a change in organic hydrogen enrichment within the middle Miocene sequence. It appears that the level of organic enrichment may be controlled by sedimentation rate, while the organic hydrogen enrichment, as shown in the hydrogen index, may reflect differences in preservation potential. Higher sedimentation rates would result in higher organic carbon contents. Higher hydrogen index values would reflect higher degrees of organic preservation resulting from more restricted circulation.

The entire penetrated section is thermally immature and has not entered into the main phase of thermal hydrocarbon generation. Neither the Rock-Eval nor the pyrolysis-gas chromatographic data indicate the presence of thermally mature, migrated, heavy hydrocarbons. This absence of mature, heavy hydrocarbons includes Cores 128-799B-65R and 128-799B-66R, which exhibited cut fluorescence onboard the ship. Therefore, the fluorescence is considered to have resulted from indigenous, thermally immature bitumens.
\end{abstract}

\section{INTRODUCTION}

Site 799 is located in the Kita-Yamato Trough in the south-central Japan Sea (Fig. 1). Three holes drilled at the site penetrated $1084 \mathrm{~m}$ of sediment. The oldest sediment recovered is early Miocene in age.

The primary objective of Site 799 was to examine the depositional and tectonic environments of massive sulfide mineralization in a failed backarc rift. A secondary objective was to obtain a detailed paleoceanographic record of this backarc setting, including possible evidence of low-oxygen water masses during the initial formation of the basin. The original drilling plans called for total penetration of approximately $1610 \mathrm{mbsf}$ (including $50 \mathrm{~m}$ of basement). However, drilling was terminated at 1084 mbsf prior to reaching this objective for safety reasons when samples from Cores 128-799B-65R and 128-799B-66R exhibited a slow, pale, yellowish-white cut fluorescence (Shipboard Scientific Party, 1990).

This study was initiated (1) to supplement the available shipboard organic geochemical data with information about downhole variability of the sedimentary organic matter and (2) to determine the significance of the cut fluorescence in Cores 128-799B-65R and 128-799B-66R. This was to include a determination about whether migrated, thermally mature, heavy hydrocarbons $\left(\mathrm{C}_{10}+\right)$ are present in the stratigraphic column and whether the penetrated section is actively generating heavy hydrocarbons.

\section{ANALYTICAL METHODS}

One hundred and eight samples were selected for analysis, based on shipboard measurements of organic carbon (Shipboard Scientific Party, 1990). The stratigraphic distribution of these samples is presented in Figure 2. Upon receipt, each sample was oven-dried at $60^{\circ} \mathrm{C}$ and ground to approximately 325 mesh $(44 \mu \mathrm{m})$. Organic carbon content $\left(\mathrm{C}_{\text {org }}\right)$ and total sulfur were determined for each sample using a LECO analyzer after decarbonation with $\mathrm{HCl}$. Each sample was also subjected to whole-rock pyrolytic assay using the Rock-Eval system described by Espitalié et al. (1977). Selected samples underwent pyrolysis-gas chromatography, as described by Colling et al. (1986). This technique utilizes a pyroprobe which flash heats the sample to $700^{\circ} \mathrm{C}$ for $5 \mathrm{~s}$, trapping the products in a liquid nitrogen cold trap. The products were then permitted to achieve thermal equilibrium with

${ }^{1}$ Pisciotto, K. A., Ingle, J. C., Jr., von Breymann, M. T., Barron, J., et al., 1992. Proc ODP, Sci. Results, 127/128, Pt. 1: College Station, TX (Ocean Drilling Program).

${ }^{2}$ Texaco Inc., E.TP.D., 3901 Briarpark, Houston, TX 77042. the initial gas chromatograph oven temperature $\left(50^{\circ} \mathrm{C}\right)$. After $18 \mathrm{~min}$, the oven temperature was increased to $225^{\circ} \mathrm{C}$ at a rate of $8^{\circ}$ per minute, and then to $310^{\circ} \mathrm{C}$ at a rate of $6^{\circ}$ per minute. This final temperature was held for $6 \mathrm{~min}$.

\section{ANALYTICAL RESULTS Organic Carbon and Total Sulfur}

Organic carbon contents ranged from 0.90 to $5.08 \mathrm{wt} \%$. These data are detailed in Table 1 and Figure 2. All of the samples contain above-average quantities of organic carbon $(>0.3 \mathrm{wt} \%$ ) relative to deep-sea sediments (McIver, 1975), and all except seven samples contain above-average quantities of organic carbon (> $1.0 \mathrm{wt} \%$ ) relative to all fine-grain sedimentary rocks (Bissada, 1982). In general, the lower and middle Miocene sections, below 454 mbsf (Core 128-799A-50X), display slightly greater levels of organic carbon enrichment than the younger sediments.

The shore-based organic carbon values measured as part of this study differ slightly from the shipboard measurements (Shipboard Scientific Party, 1990). In general, the shipboard measurements are slightly greater than the shore-based measurements (Fig. 3). Because there appears to be a systematic difference among the paired values, much of the difference may be attributable to a difference in analytical techniques. As noted previously, shore-based measurements were performed using a LECO analyzer, while shipboard values were determined by difference, with total carbon being determined using a Perkin Elmer (model 240C) CHN-elemental analyzer, while carbonate carbon was determined using a Coulometrics 5030 carbonate carbon apparatus. The generally depressed shore-based measurements may reflect losses of organic matter as a result of hydrolysis during decarbonation or depressed shipboard carbonate-carbon values because of the presence of both dolomite and siderite.

The few values that differ substantially from the observed trend may reflect sample inhomogeneity. Although measurements were performed using samples from the same intervals, they were not performed on splits of a homogenized powder.

Total sulfur data also are included in Table 1. Total sulfur contents range from 0.04 to $3.06 \mathrm{wt} \%$. The observed carbon/sulfur ratios do not appear typical of open marine sediments (Fig. 4). In general, the sediments appear to contain a slight excess of sulfur. However, the sulfur excess is less than would be expected from a euxinic environment in which free $\mathrm{H}_{2} \mathrm{~S}$ is present in the water column and sedimentary iron is available (Berner and Raiswell, 1983). The observed carbon/sulfur ratios may reflect an iron deficiency rather than differ- 


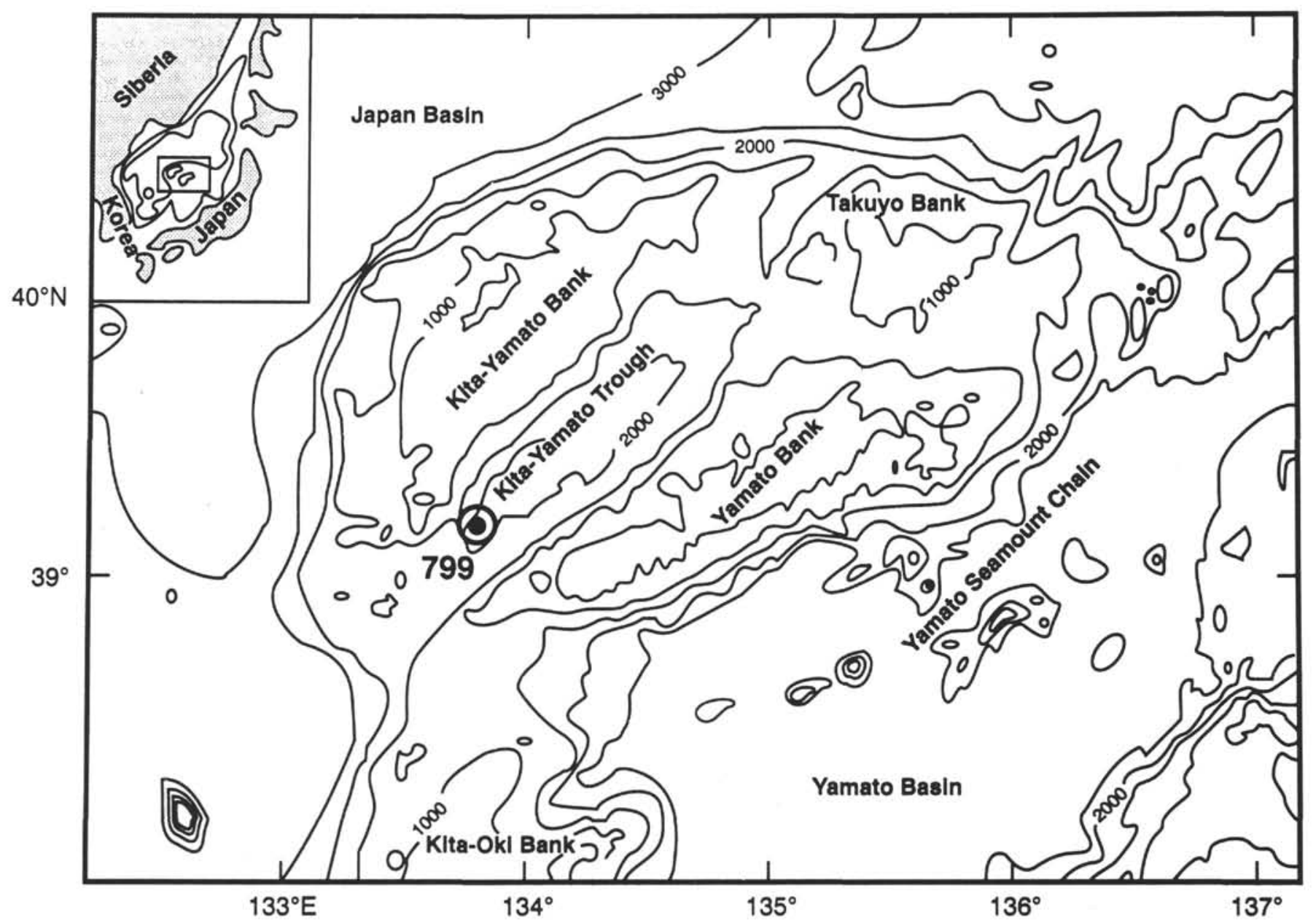

Figure 1. Location map for Site 799.

ences in the availability of either $\mathrm{O}_{2}$ or $\mathrm{H}_{2} \mathrm{~S}$ in the water column. These observations are consistent with those of the Shipboard Scientific Party (1990).

\section{Rock-Eval Pyrolysis}

Pyrolytic assay provides information about hydrocarbon generation potential, organic character, the extent of thermal diagenesis, and the presence of "reservoired" hydrocarbons. Pyrolysis results are summarized in Table 1 and Figure 2.

Total pyrolytic hydrocarbon yields $\left(S_{1}+S_{2}=\right.$ free distillable hydrocarbons $[\mathrm{HC}]+$ generatable $\mathrm{HC}$ ) range from 0.69 to $18.83 \mathrm{mg}$ $\mathrm{HC} / \mathrm{g}$ rock. Good potential and/or effective hydrocarbon source rocks yield $>6 \mathrm{mg} \mathrm{HC} / \mathrm{g}$ rock (Tissot and Welte, 1984). Within the present sample suite, sediments of this quality are limited principally to the section below $741 \mathrm{~m}$ (Core 128-799B-32R), i.e., the lower half of the middle Miocene and lower Miocene sequences. However, caution should be exercised when evaluating these data because of the suspected low levels of thermal maturity of the sediments. In samples having very low levels of thermal maturity, both the $S_{1}$ and the $S_{2}$ peaks may not contain exclusively hydrocarbons, but may instead contain significant amounts of hetero compounds (i.e., molecules containing $\mathrm{O}, \mathrm{N}$, and $\mathrm{S}$ ). The presence of these labile compounds may result in a slight overestimation of the hydrocarbon yields.

Although complicated by such factors as thermal maturity (Espitalié et al., 1985), organic enrichment and mineral matrix effects (Katz, 1983), pyrolysis can be used to provide insight into the nature of the sedimentary organic matter. This interpretation is accomplished using the hydrogen ( $\mathrm{mg}^{\text {" }} \mathrm{S}_{2}$ " $\mathrm{HC} / \mathrm{g} \mathrm{C}_{\text {org }}$ ) and oxygen ( $\mathrm{mg} \mathrm{CO}_{2} / \mathrm{g} \mathrm{C}_{\text {org }}$ ) indexes and a modified van Krevelen-type diagram, as described by Espitalié et al. (1977).

Both the hydrogen and oxygen indexes samples from Site 799 exhibit wide variability (Fig. 5). However, these data do indicate that a marked change occurs in organic facies within the middle Miocene section (Fig. 2). The organic matter in the lower portion of the column, below 740 mbsf (Core 128-799B-32R), is more hydrogen enriched than the preserved organic matter contained within the upper portion of the stratigraphic column. The sediments in the lower portion of the stratigraphic column display hydrogen indexes of $\sim 400$. This organic material might be classified type II according to the scheme of Tissot et al. (1974). Type II organic material is typically well-preserved marine organic matter. In the shallower portion of the column the hydrogen indexes typically range between 100 and 200 . This material should be classified as type III organic matter according to the scheme of Tissot et al. (1974). Type III material typically is either oxidized marine or terrestrially derived organic matter. The elevated oxygen indexes $(>\sim 150)$ are probably the combined result of an inorganic $\mathrm{CO}_{2}$ contribution from the various carbonate minerals present (calcite, dolomite, and siderite; Palacas et al., 1981; Katz, 1983), as well as a contribution from the more functionalized components, including humic acids, typical of very thermally immature sediments.

An examination (Table 1) of the two pyrolysis thermal maturity indicators, $\mathrm{T}_{\max }$ (temperature at which maximum pyrolytic hydrocarbon generation occurs) and the transformation ratio (TR $=\mathrm{S}_{1} /\left[\mathrm{S}_{1}+\right.$ $\left.\mathrm{S}_{2}\right]$ ), suggests that the penetrated section is thermally immature (i.e., has not entered the main phase of the thermal hydrocarbon genera- 

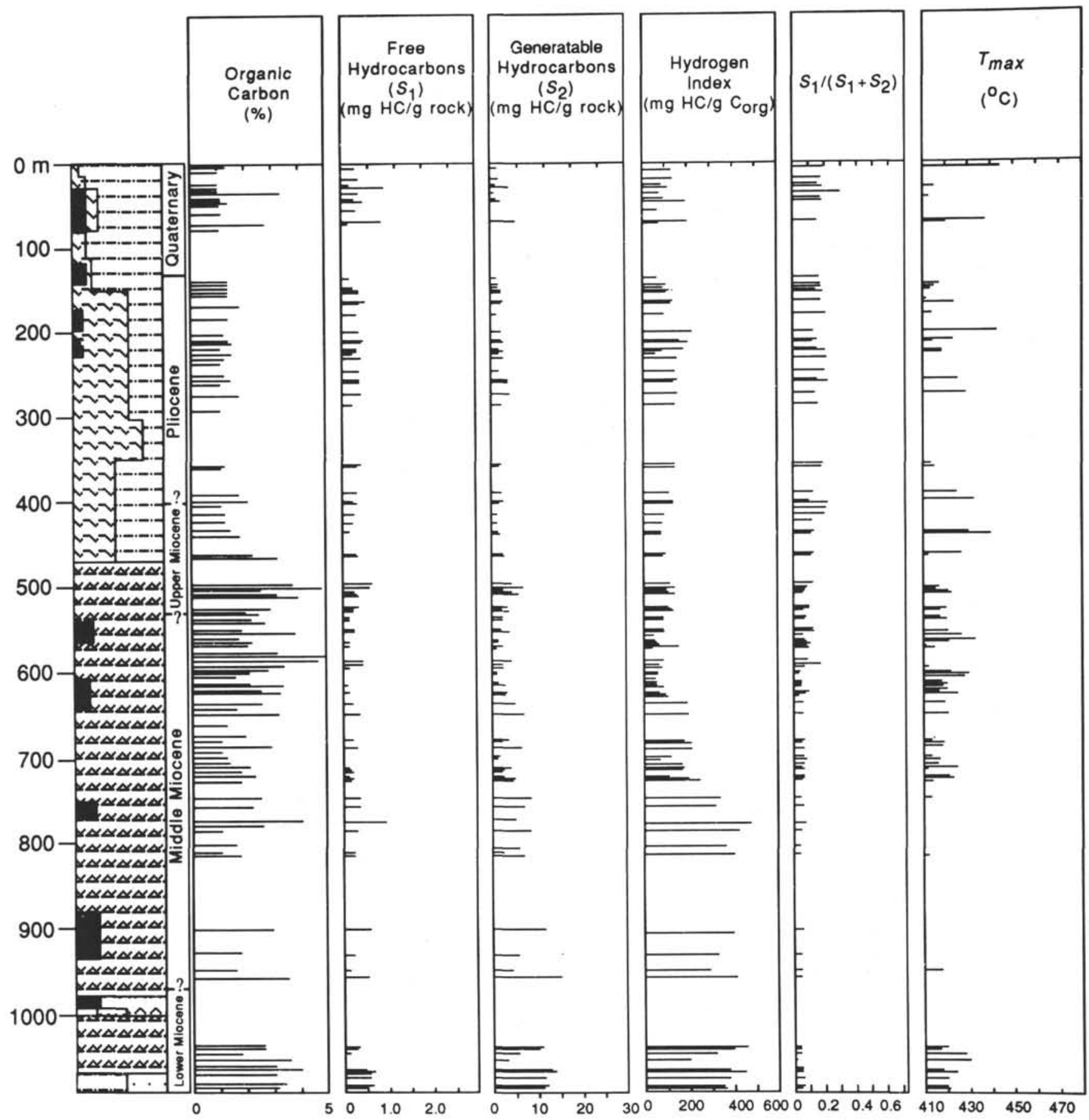

Figure 2. Lithostratigraphic and geochemical summary for Site 799.

tion). This is manifested by the typically low $\mathrm{T}_{\max }$ values of $\angle 430^{\circ} \mathrm{C}$ and the TR values of $<0.10$ in the lower half of the sedimentary sequence.

These data further suggest that several samples (e.g., 128-799A$3 \mathrm{H}-6,10-15 \mathrm{~cm}$, and $128-799 \mathrm{~A}-25 \mathrm{X}-4,113-117 \mathrm{~cm}$ ) contain high proportions of secondary, recycled, or inert organic matter. This is manifested by these samples' bimodal $\mathrm{S}_{2}$ peak. Samples showing a bimodal $S_{2}$ peak appear to be largely restricted to the upper portion of the stratigraphic column. The presence of "residual" material is consistent with the suggested kerogen type, based on the hydrogen and oxygen indexes.

Although the TR values do indicate that the penetrated section is thermally immature, the observed trend in TR is anomalous and does not represent a typically observed thermal maturation trend or profile. The highest TR values are observed in the upper portion of the sequence (Fig. 2). The inverted TR trend most probably reflects a decrease in the relative concentration of initial bitumens as a function of organic diagenesis. This inverted trend may, in part, be a result of the conversion from biopolymers represented largely in the $S_{1}$ fraction to geopolymers represented by the $\mathrm{S}_{2}$ fraction (i.e., the kerogenization process).

Although anomalously high TR values may sometimes indicate the presence of migrated heavy hydrocarbons (petroleum), such is not considered to be the case at Site 799. Hydrocarbon shows or occurrences are normally restricted to discrete intervals and typically do not display 
Table 1. Organic carbon and pyrolysis data, Site 799.

\begin{tabular}{|c|c|c|c|c|c|c|c|c|c|}
\hline $\begin{array}{l}\text { Core, section, } \\
\text { interval }(\mathrm{cm})\end{array}$ & $\begin{array}{l}\text { Depth } \\
\text { (mbsf) }\end{array}$ & $\begin{array}{l}\text { Organic } \\
\text { carbon } \\
\text { (wt\%) }\end{array}$ & $\begin{array}{l}\text { Total } \\
\text { sulfur } \\
\text { (wt\%) }\end{array}$ & \multicolumn{2}{|c|}{$\frac{\mathrm{S}_{1}}{\text { (mg HC/g rock) }}$} & $\mathrm{HI}^{\mathrm{a}}$ & $\mathrm{OI}^{\mathrm{b}}$ & $\mathrm{TR}^{\mathrm{e}}$ & $\begin{array}{l}\mathrm{T}_{\max } \\
\left({ }^{\circ} \mathrm{C}\right)\end{array}$ \\
\hline \multicolumn{10}{|l|}{$799 \mathrm{~A}$} \\
\hline $1 \mathrm{H}-1,44-49$ & 0.44 & 1.25 & 0.04 & 0.59 & 2.78 & 222 & 128 & 0.18 & 420 \\
\hline $2 \mathrm{H}-4,74-78$ & 6.44 & 1.01 & 0.70 & 0.31 & 1.32 & 130 & 140 & 0.19 & ${ }^{d} B$ \\
\hline $3 \mathrm{H}-6,10-14$ & 18.30 & 1.11 & 0.85 & 0.38 & 1.58 & 142 & 95 & 0.19 & B \\
\hline $4 \mathrm{H}-4,20-25$ & 25.00 & 0.99 & 0.40 & 0.17 & 0.84 & 84 & 213 & 0.17 & B \\
\hline $4 \mathrm{H}-6,20-25$ & 28.00 & 3.34 & 1.30 & 0.94 & 3.87 & 115 & 83 & 0.20 & 415 \\
\hline $5 \mathrm{H}-4,20-25$ & 34.60 & 1.01 & 0.89 & 0.37 & 0.78 & 76 & 478 & 0.32 & B \\
\hline $6 \mathrm{H}-2,20-25$ & 41.20 & 1.36 & 0.84 & 0.28 & 1.28 & 94 & 208 & 0.18 & 412 \\
\hline $6 \mathrm{H}-4,20-25$ & 44.20 & 1.01 & 0.66 & 0.47 & 1.94 & 191 & 75 & 0.20 & B \\
\hline $7 \mathrm{H}-4,40-45$ & 54.00 & 1.10 & 1.30 & 0.33 & 0.70 & 63 & 231 & 0.32 & $<400$ \\
\hline $8 \mathrm{H}-6,50-54$ & 66.70 & 2.70 & 1.06 & 0.91 & 5.30 & 196 & 78 & 0.15 & 437 \\
\hline $9 \mathrm{H}-2,30-35$ & 70.10 & 0.90 & 0.92 & 0.14 & 0.64 & 71 & 292 & 0.18 & 420 \\
\hline $15 \mathrm{H}-6,54-58$ & 134.14 & 1.36 & 0.81 & 0.17 & 0.83 & 61 & 283 & 0.17 & 407 \\
\hline $16 \mathrm{H}-4,60-65$ & 140.90 & 1.32 & 0.90 & 0.28 & 1.30 & 98 & 203 & 0.18 & 417 \\
\hline $16 \mathrm{H}-6,60-65$ & 143.90 & 1.41 & 0.81 & 0.26 & 1.16 & 82 & 292 & 0.18 & 415 \\
\hline $17 \mathrm{H}-2,55-60$ & 147.55 & 1.50 & 0.73 & 0.34 & 2.03 & 135 & 166 & 0.14 & B \\
\hline $17 \mathrm{H}-4,40-45$ & 150.40 & 1.42 & 0.81 & 0.34 & 1.49 & 105 & 202 & 0.19 & 409 \\
\hline $18 \mathrm{H}-4,40-45$ & 160.10 & 1.74 & 0.87 & 0.51 & 2.39 & 137 & 114 & 0.18 & 411 \\
\hline $18 \mathrm{H}-6,40-45$ & 163.10 & 1.75 & 1.20 & 0.38 & 2.22 & 127 & 226 & 0.15 & 424 \\
\hline $20 \mathrm{H}-2,20-25$ & 176.20 & 1.25 & 0.66 & 0.30 & 1.11 & 89 & 232 & 0.21 & 414 \\
\hline $22 X-2,77-81$ & 196.07 & 1.12 & 0.90 & 0.38 & 2.45 & 217 & 77 & 0.13 & 443 \\
\hline $23 X-2,29-33$ & 205.29 & 1.53 & 0.54 & 0.47 & 2.46 & 161 & 199 & 0.16 & 423 \\
\hline $23 X-4,20-24$ & 208.20 & 1.43 & 0.81 & 0.43 & 2.76 & 192 & 34 & 0.14 & 414 \\
\hline $24 X-2,132-136$ & 215.92 & 1.05 & 0.62 & 0.33 & 1.72 & 163 & 136 & 0.16 & B \\
\hline $24 X-4,98-102$ & 218.58 & 1.39 & 0.87 & 0.32 & 1.23 & 88 & 218 & 0.21 & 418 \\
\hline $24 \mathrm{X}-6,24-29$ & 222.84 & 1.19 & 0.64 & 0.18 & 0.69 & 58 & 466 & 0.21 & 418 \\
\hline $25 X-4,113-117$ & 228.43 & 0.96 & 0.45 & 0.43 & 1.50 & 155 & 4 & 0.22 & B \\
\hline $27 \mathrm{X}-2,25-29$ & 243.15 & 1.04 & 0.83 & 0.37 & 1.48 & 142 & 34 & 0.20 & 408 \\
\hline $29 X-2,25-30$ & 252.65 & 1.40 & 0.79 & 0.38 & 2.16 & 154 & 130 & 0.15 & 425 \\
\hline $29 X-4,22-27$ & 255.62 & 0.95 & 0.50 & 0.37 & 1.23 & 129 & 7 & 0.23 & $<400$ \\
\hline $30 X-6,50-55$ & 268.55 & 1.74 & 1.12 & 0.41 & 2.62 & 150 & 169 & 0.14 & 429 \\
\hline $32 X-4,50-55$ & 283.20 & 0.90 & 0.77 & 0.26 & 1.23 & 136 & 168 & 0.18 & 410 \\
\hline $39 X-4,40-44$ & 350.80 & 1.20 & 0.68 & 0.41 & 1.67 & 138 & 35 & 0.20 & 414 \\
\hline $39 X-6,40-44$ & 353.80 & 1.05 & 0.73 & 0.33 & 1.44 & 137 & 141 & 0.19 & 415 \\
\hline $42 X-6,80-85$ & 383.30 & 1.74 & 0.74 & 0.30 & 2.08 & 119 & 211 & 0.13 & 425 \\
\hline $43 X-6,40-45$ & 392.50 & 1.99 & 1.06 & 0.26 & 2.57 & 129 & 183 & 0.09 & 432 \\
\hline $44 X-2,10-15$ & 395.90 & 0.91 & 0.50 & 0.33 & 1.20 & 132 & 37 & 0.22 & $<400$ \\
\hline $45 \times-4,47-52$ & 408.87 & 1.11 & 0.87 & 0.28 & 1.04 & 93 & 45 & 0.21 & $<400$ \\
\hline $46 X-4,20-25$ & 418.30 & 1.07 & 0.54 & 0.25 & 0.97 & 90 & 44 & 0.20 & 405 \\
\hline $47 X-4,126-130$ & 429.06 & 1.37 & 0.93 & 0.15 & 1.04 & 75 & 449 & 0.13 & 430 \\
\hline $47 X-6,144-148$ & 432.24 & 1.69 & 1.16 & 0.08 & 1.29 & 76 & 343 & 0.06 & 440 \\
\hline $50 X-2,88-92$ & 454.68 & 2.12 & 1.09 & 0.31 & 2.01 & 94 & 263 & 0.13 & 427 \\
\hline $50 \times-4,93-97$ & 457.73 & 3.07 & 1.15 & 0.34 & 2.75 & 89 & 53 & 0.11 & 412 \\
\hline
\end{tabular}

799B

$\begin{array}{lrllllrrrr}\text { 5R-1, 90-94 } & 490.50 & 3.61 & 1.17 & 0.63 & 4.32 & 119 & 46 & 0.13 & 410 \\ \text { 6R-1, 33-38 } & 494.93 & 4.92 & 2.07 & 0.61 & 6.69 & 136 & 57 & 0.08 & 417 \\ \text { 6R-2, 10-15 } & 496.20 & 2.42 & 0.97 & 0.19 & 2.47 & 102 & 57 & 0.07 & 415 \\ \text { 7R-1, 20-25 } & 499.90 & 3.10 & 1.00 & 0.32 & 4.06 & 130 & 52 & 0.07 & 421 \\ \text { 7R-3, 30-35 } & 503.00 & 3.85 & 1.18 & 0.36 & 5.50 & 142 & 70 & 0.06 & 422 \\ 8 R-6,16-20 & 516.96 & 2.85 & 1.29 & 0.35 & 3.06 & 107 & 50 & 0.10 & 409 \\ \text { 9R-2,91-95 } & 521.41 & 1.77 & 1.57 & 0.23 & 2.37 & 134 & 109 & 0.09 & 420 \\ \text { 9R-4, 123-127 } & 524.73 & 2.40 & 1.63 & 0.24 & 3.51 & 146 & 72 & 0.06 & 417 \\ \text { 10R-2, 127-131 } & 531.37 & 2.02 & 1.12 & 0.15 & 1.70 & 83 & 50 & 0.08 & 417 \\ \text { 10R-4, 64-67 } & 533.74 & 2.57 & 1.10 & 0.15 & 2.10 & 81 & 132 & 0.07 & 420 \\ \text { 11R-5, 29-31 } & 544.59 & 1.67 & 0.61 & 0.22 & 1.49 & 89 & 39 & 0.13 & 400 \\ \text { 11R-7, 32-35 } & 547.62 & 3.78 & 1.45 & 0.21 & 3.62 & 95 & 61 & 0.05 & 421 \\ \text { 12R-4, 71-74 } & 553.11 & 1.58 & 0.51 & 0.04 & 0.65 & 41 & 394 & 0.06 & 427 \\ \text { 13R-1, 56-61 } & 558.16 & 2.10 & 1.60 & 0.07 & 1.17 & 55 & 174 & 0.06 & 433 \\ \text { 13R-3, 60-65 } & 561.20 & 1.93 & 1.52 & 0.15 & 1.31 & 67 & 222 & 0.10 & 421 \\ \text { 14R-1, 85-90 } & 568.15 & 2.22 & 1.56 & 0.08 & 0.85 & 38 & 380 & 0.09 & 415 \\ \text { 14R-3, 55-60 } & 570.85 & 3.03 & 1.47 & 0.23 & 1.87 & 61 & 21 & 0.11 & 416 \\ \text { 15R-1, 25-30 } & 577.25 & 5.08 & 1.62 & 0.89 & 8.09 & 159 & 21 & 0.10 & 414 \\ \text { 15R-4, 5-10 } & 581.55 & 4.92 & 2.16 & 0.43 & 4.24 & 86 & 39 & 0.09 & 400 \\ \text { 16R-1, 80-85 } & 587.40 & 3.21 & 1.97 & 0.43 & 2.16 & 67 & 23 & 0.17 & <400 \\ \text { 16R-3, 110-115 } & 590.70 & 2.71 & 0.88 & 0.15 & 2.07 & 76 & 58 & 0.07 & 412 \\ \text { 17R-1, 25-30 } & 596.55 & 1.88 & 0.98 & 0.04 & 0.98 & 52 & 60 & 0.04 & 422 \\ \text { 17R-3, 35-40 } & 599.65 & 1.96 & 0.68 & 0.04 & 1.19 & 60 & 112 & 0.03 & 430 \\ \text { 17R-5, 30-35 } & 602.60 & 1.46 & 0.82 & 0.03 & 0.67 & 45 & 119 & 0.04 & 428 \\ \text { 18R-1, 143-147 } & 607.33 & 1.96 & 1.23 & 0.05 & 1.07 & 54 & 112 & 0.04 & 418 \\ \text { 18R-3, 89-91 } & 609.79 & 3.20 & 1.01 & 0.11 & 2.71 & 84 & 70 & 0.04 & 420 \\ \text { 18R-4, 139-141 } & 611.79 & 1.92 & 1.30 & 0.05 & 1.13 & 58 & 53 & 0.04 & 419 \\ \text { 19R-1, 77-81 } & 616.37 & 2.47 & 1.01 & 0.07 & 1.78 & 71 & 63 & 0.04 & 420 \\ \text { 19R-3, 80-84 } & 619.40 & 3.10 & 0.87 & 0.15 & 3.11 & 100 & 24 & 0.05 & 412\end{array}$


Table 1 (continued).

\begin{tabular}{|c|c|c|c|c|c|c|c|c|c|}
\hline \multirow{2}{*}{$\begin{array}{l}\text { Core, section, } \\
\text { interval }(\mathrm{cm})\end{array}$} & \multirow{2}{*}{$\begin{array}{l}\text { Depth } \\
\text { (mbsf) }\end{array}$} & \multirow{2}{*}{$\begin{array}{l}\text { Organic } \\
\text { carbon } \\
(w t \%)\end{array}$} & \multirow{2}{*}{$\begin{array}{l}\text { Total } \\
\text { sulfur } \\
\text { (wt\%) }\end{array}$} & & & \multirow[b]{2}{*}{$\mathrm{HI}^{\mathrm{a}}$} & \multirow[b]{2}{*}{$\mathrm{OI}^{\mathrm{b}}$} & \multirow[b]{2}{*}{$\mathrm{TR}^{\mathrm{c}}$} & \multirow{2}{*}{$\underset{\left({ }^{\circ} \mathrm{C}\right)}{\mathrm{T}_{\max }}$} \\
\hline & & & & \multicolumn{2}{|c|}{$\overline{(\mathrm{mg} \mathrm{HC} / \mathrm{g} \text { rock) }}$} & & & & \\
\hline $19 \mathrm{R}-5,55-59$ & 622.15 & 2.43 & 1.00 & 0.07 & 2.70 & 111 & 30 & 0.03 & 425 \\
\hline $20 \mathrm{R}-5,108-112$ & 632.28 & 2.40 & 1.00 & 0.26 & 4.64 & 193 & 19 & 0.05 & 419 \\
\hline $21 \mathrm{R}-3,80-84$ & 638.70 & 1.53 & 0.39 & 0.09 & 1.20 & 78 & 102 & 0.07 & 417 \\
\hline $22 \mathrm{R}-1,6-9$ & 644.66 & 3.17 & 0.99 & 0.34 & 6.42 & 202 & 19 & 0.05 & 421 \\
\hline $23 \mathrm{R}-2,50-55$ & 656.20 & 1.17 & 0.81 & 0.15 & 1.82 & 154 & 22 & 0.08 & 411 \\
\hline $25 \mathrm{R}-1,60-65$ & 674.10 & 1.78 & 0.94 & 0.24 & 3.21 & 180 & 20 & 0.07 & 413 \\
\hline $25 R-3,90-95$ & 677.40 & 1.09 & 0.72 & 0.10 & 2.27 & 207 & 54 & 0.04 & 419 \\
\hline $26 \mathrm{R}-1,120-125$ & 684.40 & 2.85 & 0.98 & 0.30 & 6.04 & 212 & 59 & 0.05 & 418 \\
\hline $27 \mathrm{R}-1,108-112$ & 693.58 & 1.10 & 1.23 & 0.09 & 1.30 & 117 & 24 & 0.06 & 413 \\
\hline $27 \mathrm{R}-3,112-117$ & 696.62 & 0.98 & 1.15 & 0.06 & 0.72 & 73 & 113 & 0.08 & 417 \\
\hline $28 \mathrm{R}-1,40-45$ & 702.50 & 1.19 & 0.99 & 0.12 & 1.96 & 164 & 32 & 0.06 & 416 \\
\hline $28 \mathrm{R}-3,40-45$ & 705.50 & 2.01 & 0.98 & 0.14 & 3.68 & 182 & 91 & 0.04 & 425 \\
\hline $28 \mathrm{R}-5,40-45$ & 708.50 & 1.58 & 1.27 & 0.18 & 2.61 & 165 & 25 & 0.06 & 411 \\
\hline $29 \mathrm{R}-2,100-105$ & 714.30 & 1.70 & 0.77 & 0.12 & 2.35 & 138 & 38 & 0.05 & 421 \\
\hline $29 R-4,75-80$ & 717.05 & 2.20 & 0.99 & 0.21 & 4.41 & 200 & 48 & 0.05 & 423 \\
\hline $30 \mathrm{R}-1,85-87$ & 722.25 & 1.62 & 1.40 & 0.17 & 4.07 & 251 & 4 & 0.04 & 414 \\
\hline $32 \mathrm{R}-1,59-61$ & 741.09 & 2.40 & 1.07 & 0.37 & 8.32 & 347 & 63 & 0.04 & 413 \\
\hline $33 \mathrm{R}-1,69-72$ & 750.89 & 2.11 & 1.42 & 0.35 & 6.90 & 326 & 16 & 0.05 & 402 \\
\hline $35 \mathrm{R}-2,42-44$ & 771.42 & 3.91 & 1.97 & 1.17 & 18.83 & 481 & 9 & 0.06 & 403 \\
\hline $36 \mathrm{R}-1,137-141$ & 780.57 & 1.98 & 1.09 & 0.32 & 8.47 & 428 & 23 & 0.04 & 408 \\
\hline $38 \mathrm{R}-1,65-67$ & 799.15 & 1.47 & 0.74 & 0.23 & 5.40 & 366 & 62 & 0.04 & 410 \\
\hline $39 \mathrm{R}-1,103-105$ & 809.13 & 1.69 & 0.88 & 0.27 & 6.85 & 405 & 17 & 0.04 & 412 \\
\hline $48 \mathrm{R}-2,96-100$ & 897.06 & 2.86 & 1.39 & 0.62 & 11.68 & 407 & 8 & 0.05 & 408 \\
\hline $51 \mathrm{R}-2,78-82$ & 925.58 & 1.72 & 1.08 & 0.26 & 5.72 & 331 & 4 & 0.04 & 409 \\
\hline $53 \mathrm{R}-2,0-4$ & 944.10 & 1.40 & 1.00 & 0.17 & 4.20 & 300 & 2 & 0.04 & 418 \\
\hline $54 \mathrm{R}-1,19-23$ & 952.39 & 3.52 & 1.83 & 0.56 & 14.94 & 424 & 33 & 0.04 & 410 \\
\hline $62 \mathrm{R}-2,13-17$ & 1031.13 & 2.33 & 1.54 & 0.33 & 10.84 & 464 & 12 & 0.03 & 420 \\
\hline $62 R-4,44-48$ & 1034.44 & 2.44 & 1.31 & 0.32 & 9.76 & 400 & 36 & 0.03 & 417 \\
\hline $63 R-1,119-123$ & 1040.29 & 1.73 & 0.74 & 0.15 & 5.44 & 313 & 7 & 0.03 & 428 \\
\hline $64 \mathrm{R}-1,0-4$ & 1048.80 & 1.61 & 1.02 & 0.08 & 3.24 & 201 & 9 & 0.09 & 430 \\
\hline $65 \mathrm{R}-1,83-85$ & 1059.23 & 3.38 & 2.00 & 0.50 & 12.75 & 377 & 1 & 0.04 & 418 \\
\hline $65 R-2,130-132$ & 1061.20 & 3.68 & 2.58 & 0.66 & 14.06 & 381 & 7 & 0.04 & 424 \\
\hline $65 \mathrm{R}-3,14-16$ & 1061.54 & 3.02 & 2.17 & 0.59 & 13.65 & 451 & 0 & 0.04 & 418 \\
\hline $65 \mathrm{R}-3,42-44$ & 1061.82 & 2.80 & 2.76 & 0.49 & 10.43 & 372 & 6 & 0.04 & 423 \\
\hline $66 \mathrm{R}-2,53-55$ & 1069.22 & 2.94 & 2.74 & 0.59 & 11.26 & 382 & 9 & 0.05 & 420 \\
\hline $67 R-1,51-53$ & 1078.21 & 3.25 & 2.43 & 0.65 & 11.70 & 360 & 11 & 0.05 & 420 \\
\hline $67 \mathrm{R}-3,72-74$ & 1081.42 & 3.04 & 3.06 & 0.51 & 11.18 & 367 & 12 & 0.04 & 421 \\
\hline
\end{tabular}

${ }^{\mathrm{a}}$ Hydrogen Index (mg " $\mathrm{S}_{2}$ " $\mathrm{HC} / \mathrm{g} \mathrm{C}_{\mathrm{org}}$ ).

${ }^{b}$ Oxygen Index ( $\mathrm{mg} \mathrm{CO}_{2} / \mathrm{g} \mathrm{C}_{\text {org }}$ ).

${ }^{c}$ Transformation Ratio $\mathrm{S}_{1} /\left(\mathrm{S}_{1}+\mathrm{S}_{2}\right)$.

${ }^{\mathrm{d}}$ Bimodal $\mathrm{S}_{2}$ peak.

a depth trend. In addition, the samples with the elevated TR values do not consistently display unusually low $\mathrm{T}_{\max }$ values $\left(<400^{\circ} \mathrm{C}\right)$, which would be typical for a hydrocarbon show.

The general absence of nonindigenous (stains and/or drilling contaminants) hydrocarbons is consistent with the relationship between TR and $\mathrm{T}_{\max }$ (Fig. 6), although several samples from Cores 128-799A-29X, 128-799A-44X, 128-799A-45X, and 128-799B-16R display slightly elevated TR values. The absence of nonindigenous hydrocarbons is also consistent with the relationship between $\mathrm{S}_{1}$ and $C_{\text {org }}$ (Fig. 7), in which all samples display low $S_{1} / C_{\text {org }}$ values.

It is important to emphasize that the Rock-Eval data do not indicate the presence of migrated hydrocarbons in Cores 128-799B-65R, 128-799B-66R, or 128-799B-67R.

\section{Pyrolysis-Gas Chromatography}

Pyrolysis-gas chromatography provides additional information about the nature of kerogen (Larter and Douglas, 1980), as well as qualitative assessment of principal hydrocarbon products that may have been generated upon thermal maturation (Dembicki et al., 1983).

The chromatographic signatures obtained for all of the analyzed samples generally lack higher-molecular-weight, waxy, alkanealkene doublets. The best developed alkane-alkene doublets typically range from $\mathrm{C}_{13}$ to $\mathrm{C}_{19}$. The lighter-end fraction is a complex hydrocarbon mixture that includes numerous aromatic species. In the higher molecular-weight range, a single peak tends to dominate in all sam- ples independent of stratigraphic position or hydrogen index. This peak has tentatively been identified through its mass spectrum as squalene. Several samples (e.g., 128-799B-35R-2, 42-44 cm; Fig. 8D) also exhibit a well-developed naphthenic envelope. These same samples also appear to display the best-developed and most complete series of alkane-alkene doublets. In addition, these samples display a clearly defined harmonic decrease in peak height with increasing carbon number.

These characteristics may be largely independent of the hydrogen index value. Note the similarity in the chromatograms obtained from Samples 128-799B-6R-1, 33-38 cm, and 128-799B-35R-2, 42$44 \mathrm{~cm}$ (Figs. 8B and 8D), with hydrogen indexes of 136 and 481, respectively. This similarity in chromatographic character suggests that some of the hydrogen indexes may be depressed by the present of "inert" (strongly oxidized or recycled) organic matter, which contributes to the total organic carbon content but does not contribute to the hydrocarbon yield (Katz, 1988).

The poor peak development in samples (such as 128-799A-8H-6, $50-54 \mathrm{~cm}$; Fig. 8A) is typical of samples containing organic matter that includes a large inert component. Such an interpretation is consistent with the slightly elevated $\mathrm{T}_{\max }$ value of $437^{\circ} \mathrm{C}$ compared to the expected level of thermal maturity, based on the sample's age (Quaternary), depth of burial (66.70 mbsf), and in situ temperature $\left(\sim 7^{\circ} \mathrm{C}\right.$; Shipboard Scientific Party, 1990).

The absence of abundant waxy components $\left(n \mathrm{C}_{22}+\right)$ suggests that the reactive or "live" organic matter does not contain a significant 


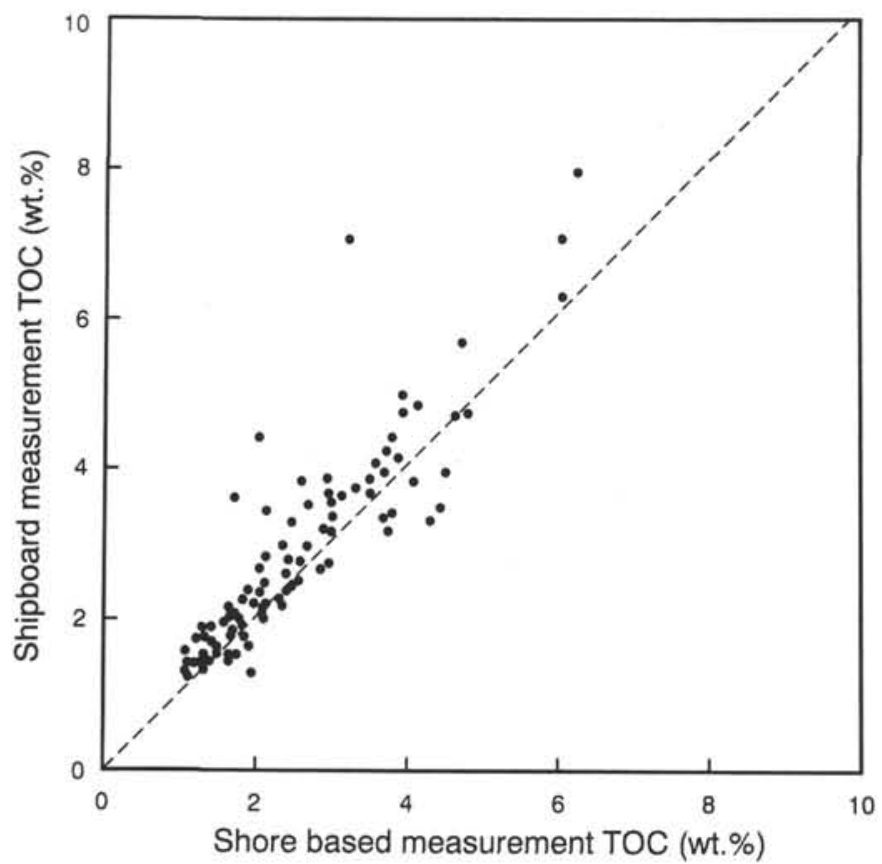

Figure 3. Comparison of shipboard with shore-based organic carbon determinations.

terrestrial component and was, in general, autochthonous (i.e., marine-derived). Such an interpretation is consistent with the presence of a naphthenic envelope, a harmonic decrease in peak height in some samples, as well as the presence of squalene, which has been found in planktonic organic detritus (Saliot et al., 1988). Differences in the calculated hydrogen indexes may reflect differences in the degree of preservation of the organic matter and/or the relative abundance of residual organic matter. The lower hydrogen index values might indicate poorer organic preservation and/or a larger relative proportion of residual organic matter. A common "live" organic matter source for the entire stratigraphic sequence is also consistent with the abundance of squalene in all of the pyrolysates.

The pyrolysis-gas chromatograph may also be used to thermally extract and analyze the $S_{1}$ hydrocarbons. These results are presented in Figure 9. Unlike mature extracts, which should be dominated by $n$-alkanes, these chromatograms are dominated by the isoprenoids pristane and phytane. $n$-alkanes are either absent or present in only trace quantities relative to the two isoprenoids. Such a chromatographic pattern is consistent throughout the penetrated section, including Cores 128-799B-65R and 128-799B-66R, which exhibited cut fluorescence on-board the ship.

As expected, a downhole increase in the complexity of the chromatographic pattern reflects the onset of thermal hydrocarbon generation, but not the presence of thermally mature hydrocarbons.

These thermal extracts also display variations in the pristane/phytane ratio and the relative abundance of specific compounds. For example, the pristane/phytane ratio of Sample 128-799B-65R-3, $14-16 \mathrm{~cm}$, is $\sim 1.0$ (Fig. 9D) compared with $0.44-0.66$ observed in the other samples. Such differences probably reflect temporal changes in both the biomass and the depositional environment.

\section{DISCUSSION}

Although all of the samples selected for this study were organically enriched, samples from the lower portion of the stratigraphic section (deeper than $454 \mathrm{mbsf}$; lower and middle Miocene) generally contain more organic matter than the shallow section. In addition, samples deeper than 740 mbsf display the most elevated hydrogen indexes. The discordance between organic enrichment and organic-

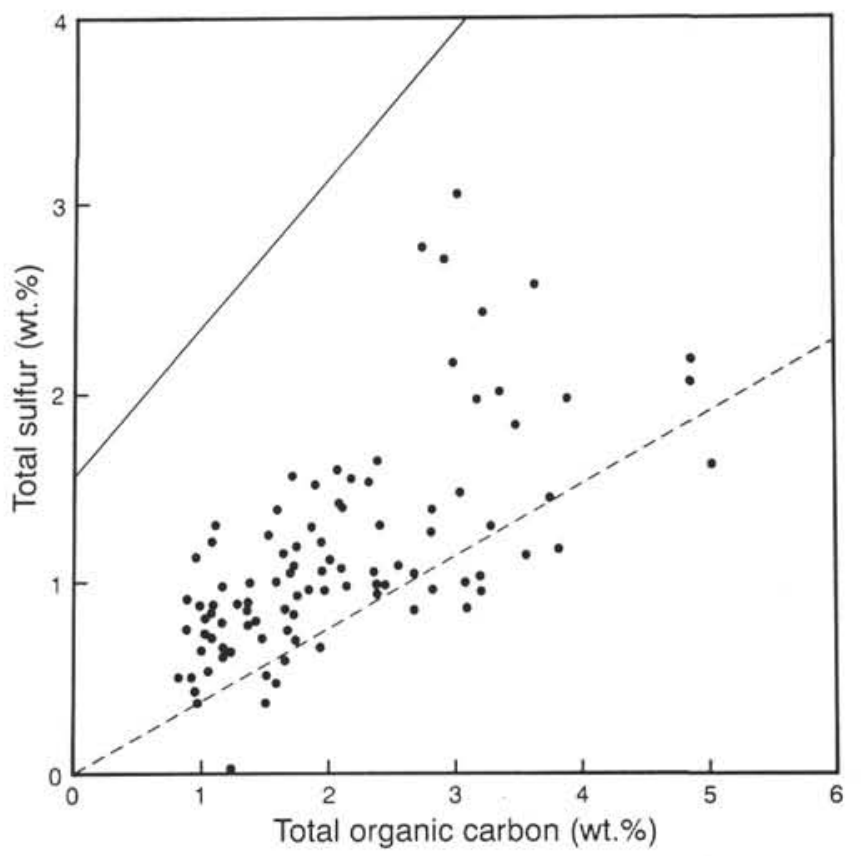

Figure 4. Relationship between total organic carbon and total sulfur. Dashed line $=$ observed relationship for normal, modern marine sediments. Solid line = observed relationship for euxinic sediments of the Black Sea (Berner and Raiswell, 1983).

hydrogen enrichment suggests possibly independent enrichment mechanisms. It is possible that the differences in organic carbon reflect differences in sedimentation rate, with higher TOC's associated with higher sedimentation rates (Müller and Suess, 1979), while differences in the hydrogen indexes may reflect differences in preservation efficiencies, with higher hydrogen index values reflecting better preservation, possibly as a result of more restricted circulation.

Kayoma et al. (1973) observed that organic hydrogen decreases at a greater rate than organic nitrogen, which in turn decreases at a more rapid rate than organic carbon during biochemical degradation of organic matter. Thus, the depletion in organic hydrogen associated with relatively constant organic carbon contents observed at Site 799 is probably the result of differences in the relative rates of elemental decomposition.

Possibly the most important results of this work are associated with the findings concerning the presence and generation of heavy hydrocarbons. The Rock-Eval maturity indexes clearly indicate that the penetrated section is thermally immature and has not yet entered into the main phase of hydrocarbon generation. This is consistent with the sediment's age, depth of burial, and geothermal gradient $\left(98^{\circ} \mathrm{C} / \mathrm{km}\right.$; Shipboard Scientific Part, 1990). In addition, these data indicate that migrated heavy hydrocarbons are not present within the penetrated section. No heavy hydrocarbon anomalies were detected, and those hydrocarbons that were observed appear to be thermally immature. Although the thermal extracts display increased complexity with depth, probably as a result of thermal hydrocarbon generation, such changes in composition are most probably associated with the earliest phases of thermogenic hydrocarbon generation. This interpretation is consistent with the Rock-Eval data and the interpretation of the volatile hydrocarbons by the shipboard party (Shipboard Scientific Party, 1990), who noted the presence of significant quantities of neopentane.

Although it was prudent and necessary to terminate drilling prior to reaching Site 799's objective, because of the observed cut fluorescence and the lack of shipboard data to determine the nature of the fluorescing material, this post-cruise investigation indicates that drilling might have proceeded safely if a more complete hydrocarbon monitoring program had been in use. This interpretation is significant 


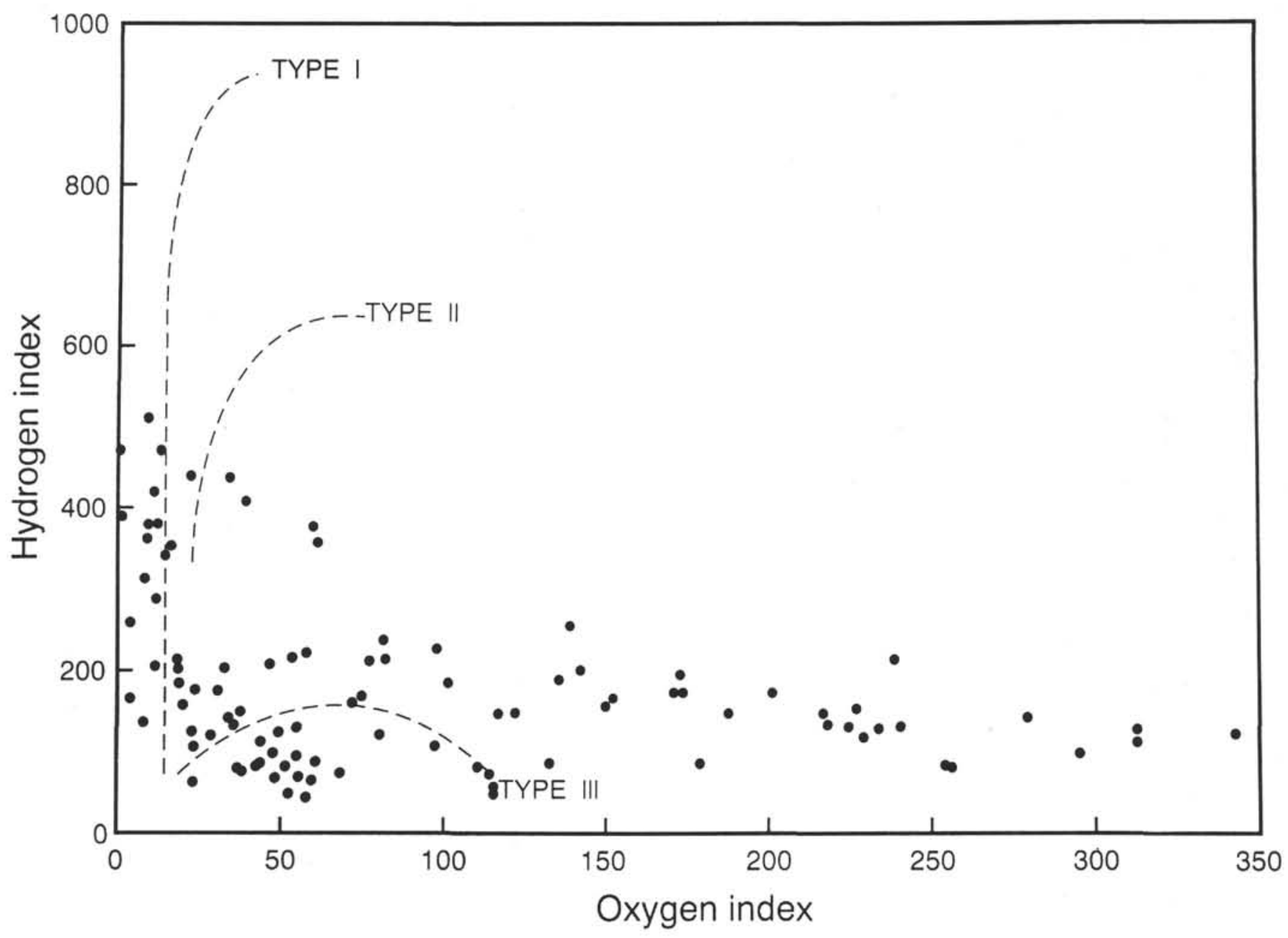

Figure 5. Modified van Krevelen-type diagram using the pyrolysis-derived hydrogen and oxygen indexes.

because a re-entry cone was left at the site and drilling might resume at Site 799 if the JOIDES Resolution returns to the Japan Sea.

\section{SUMMARY}

1. The lower portion (middle and lower Miocene) of the stratigraphic section is generally more enriched in both organic carbon and organic hydrogen. It appears that there may be different causes for the organic carbon and organic hydrogen enrichment. Organic carbon enrichment may reflect elevated sedimentation rates, while organic hydrogen enrichment may reflect increased preservation resulting from more restricted circulation.

2. Rock-Eval data do not indicate the presence of migrated heavy hydrocarbons in Cores 128-799B-65R, 128-799B-66R, or 128-799B$67 \mathrm{R}$. Nor do these data indicate that the penetrated section experienced the necessary burial/thermal history for beginning the catagenic generation and expulsion of heavy hydrocarbons. This low level of thermal maturity is manifested in both Rock-Eval indexes.

3. The chromatographic fingerprint of the $S_{1}$ peaks obtained from Cores 128-799B-65R, 128-799B-66R, and 128-799B-67R are consistent with thermally immature bitumens and are similar to those obtained in the shallow portion of the section (Core 128-799A-4H). The thermal extracts are dominated by the isoprenoids pristane and phytane.

4. A decision to continue drilling could have been justified if a more complete shipboard hydrocarbon monitoring program had been in use on Leg 128.

\section{ACKNOWLEDGMENTS}

The author thanks Texaco Inc. for permission to publish this research. Samples were supplied by Marta T. von Breymann of the Ocean Drilling Program. Analytical support was provided by Theola Breaux, Mike Darnell, and Thomas Jorjorian. Mary Hill provided editorial assistance with the original manuscript. Vaughn D. Robison, George E. Claypool, and Kay Emeis provided critical reviews of an earlier version of this manuscript.

\section{REFERENCES}

Berner, R. A., and Raiswell, R., 1983. Burial of organic carbon and pyrite sulfur in sediments over Phanerozoic time: a new theory. Geochim. Cosmochim. Acta, 47:855-862.

Bissada, K. K., 1982. Geochemical constraints on petroleum generation and migration-a review. Proc. 2nd ASCOPE Conf. Exhib., 69-87.

Colling, E. L., Burda, B. H., and Kelley, P. A., 1986. Multidimensional pyrolysis-gas chromatography: applications in petroleum geochemistry. J. Chromatogr. Sci., 24:7-12.

Dembicki, H., Jr., Horsfield, B., and Ho, T.T.Y., 1983. Source rock evaluation by pyrolysis-gas chromatography. AAPG Bull., 67:1094-1103.

Espitalié, J., Deroo, G., and Marquis, F., 1985. La pyrolyse Rock-Eval et ses applications. Rev. Inst. Fr. Pet., 40:563-579.

Espitalié, J., Madec, M., Tissot, B., Menning, J. J., and Leplat, P., 1977. Source rock characterization methods for petroleum exploration. Proc. 9th Annu. Offshore Technol. Conf., 3:439-443. 
Katz, B. J., 1983. Limitations of "Rock-Eval" pyrolysis for typing organic matter. Org. Geochem., 4:194-199.

1988. Clastic and carbonate lacustrine systems: an organic geochemical comparison (Green River Formation and East African lake sediments). In Fleet, A. J., Kelts, K., and Talbot, M. R. (Eds.), Lacustrine Petroleum Source Rocks. Geol. Soc. Spec. Publ. London, 81-90.

Koyama, T., Nikaido, M., Tomino, T., and Hayakawa, H., 1973. Decomposition of organic matter in lake sediments. Proc. Symp. Hydrogeochem. Biogeochem., 2:512-535.

Larter, S. R., and Douglas, A. G., 1980. A pyrolysis-gas chromatographic method for kerogen typing. In Douglas, A., and Maxwell, J. R. (Eds.), Advances in Organic Geochemistry, 1979: New York (Pergamon Press), 584-597.

McIver, R. D., 1975. Hydrocarbon occurrences from JOIDES Deep Sea Drilling Project cores. Proc. 9th World Pet. Congr.: London (Applied Science Publ.), 2:269-280.

Müller, P. J., and Suess, E., 1979. Productivity, sedimentation rate and sedimentary organic carbon in the oceans. I. Organic carbon preservation. Deep Sea Res. Part A, 26A:1347-1362.
Palacas, J. G., Daws, T. A., and Applegate, A. V., 1981. Preliminary petroleum source-rock assessment of Pre-Punta Gorda rocks (lowermost Cretaceous-Jurassic?) in south Florida. Trans. Gulf Coast Assoc. Geol. Soc., 31:369-376.

Saliot, A., Tronczynski, J., Scribe, P., and Letolle, R., 1988. The application of isotopic and biogeochemical markers to the study of biogeochemistry of organic matter in a macrotidal estuary, the Loire, France. Est. Coast. Shelf Sci., 27:645-669.

Shipboard Scientific Party, 1990. Site 799. In Ingle, J. C., Jr., Suyehiro, K., von Breymann, M. T., et al., Proc. ODP, Init. Repts., 128: College Station, TX (Ocean Drilling Program), 237-402.

Tissot, B., Durand, B., Espitalié, J., and Combaz, A., 1974. Influence of nature and diagenesis of organic matter in formation of petroleum. AAPG Bull. 58:499-506.

Tissot, B. P., and Welte, D. H., 1984. Petroleum Formation and Occurrence (2nd ed.): New York (Springer-Verlag).

Date of initial receipt: 30 January 1991

Date of acceptance: 29 August 1991

Ms 127/128B-163

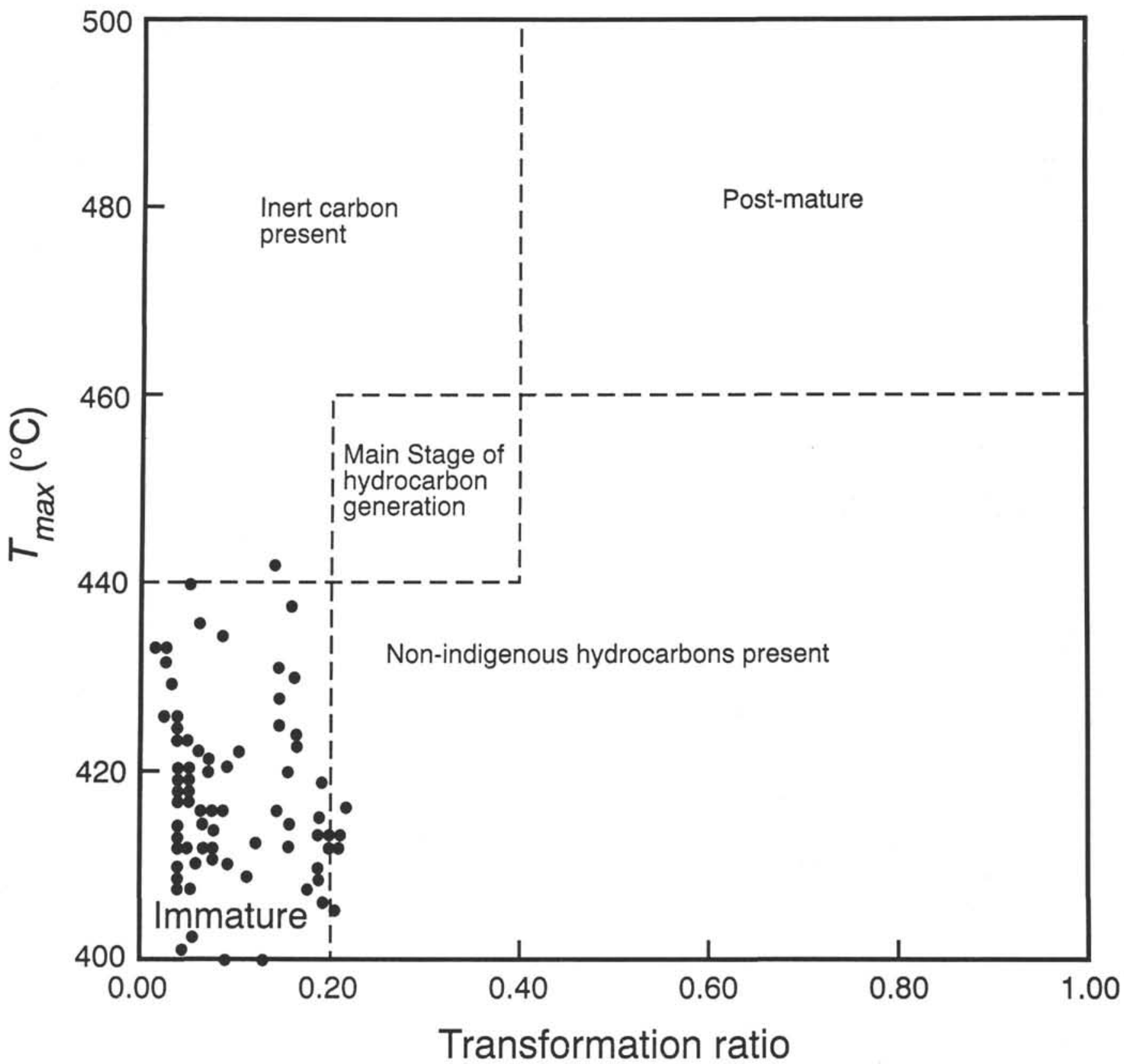

Figure 6. Relationship between $\mathrm{T}_{\max }$ and TR, permitting an assessment of thermal maturity, the presence of inert carbon, and nonindigenous hydrocarbons. 


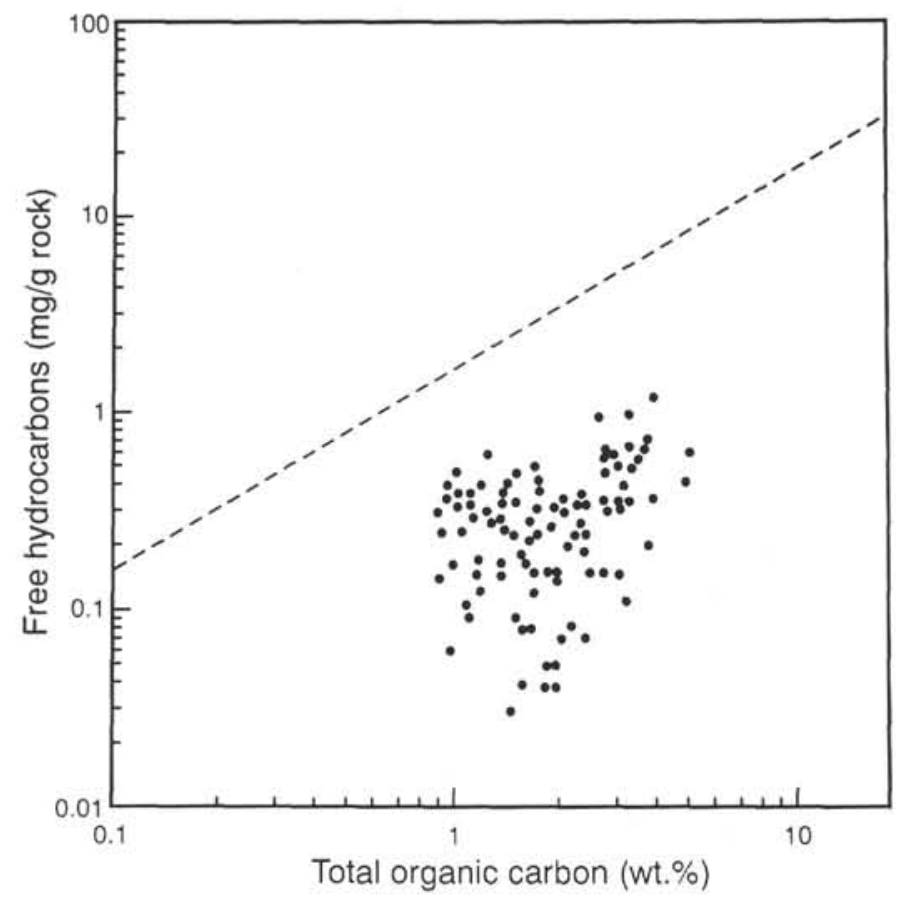

Figure 7. Relationship between $S_{1}$ yield and total organic carbon. Any samples plotting above the dashed line typically are contaminated or contain migrated hydrocarbons. 

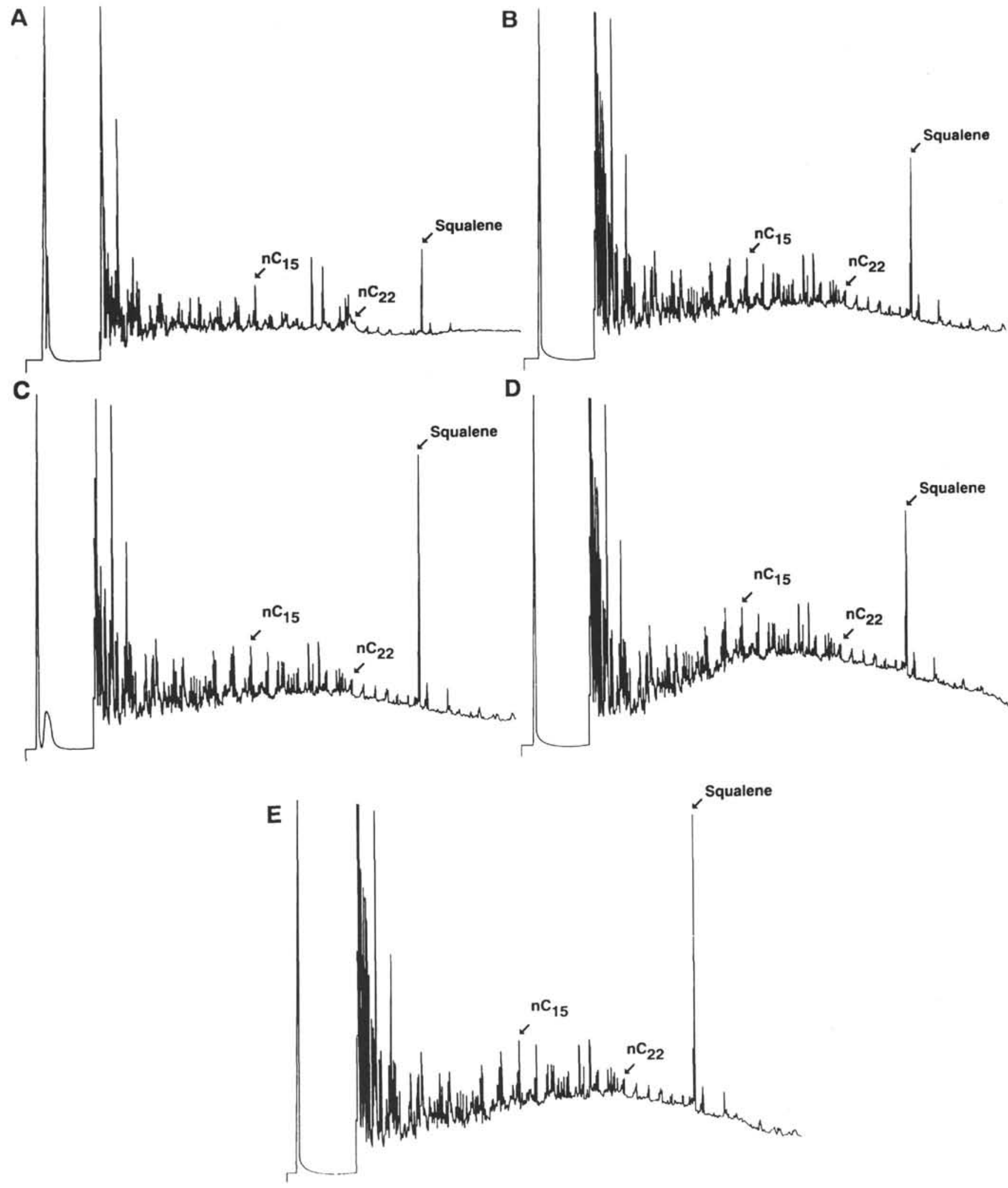

Figure 8. Pyrolysis-gas chromatograms. A. Sample 128-799A-8H-6, 50-54 cm. B. Sample 128-799B-6R-1, 33-38 cm. C. Sample 128-799B-22R-1, 6-9 cm. D. Sample 128-799B-35R-2, 42-44 cm. E. Sample 128-799B-67R-3, 9-11 cm. 

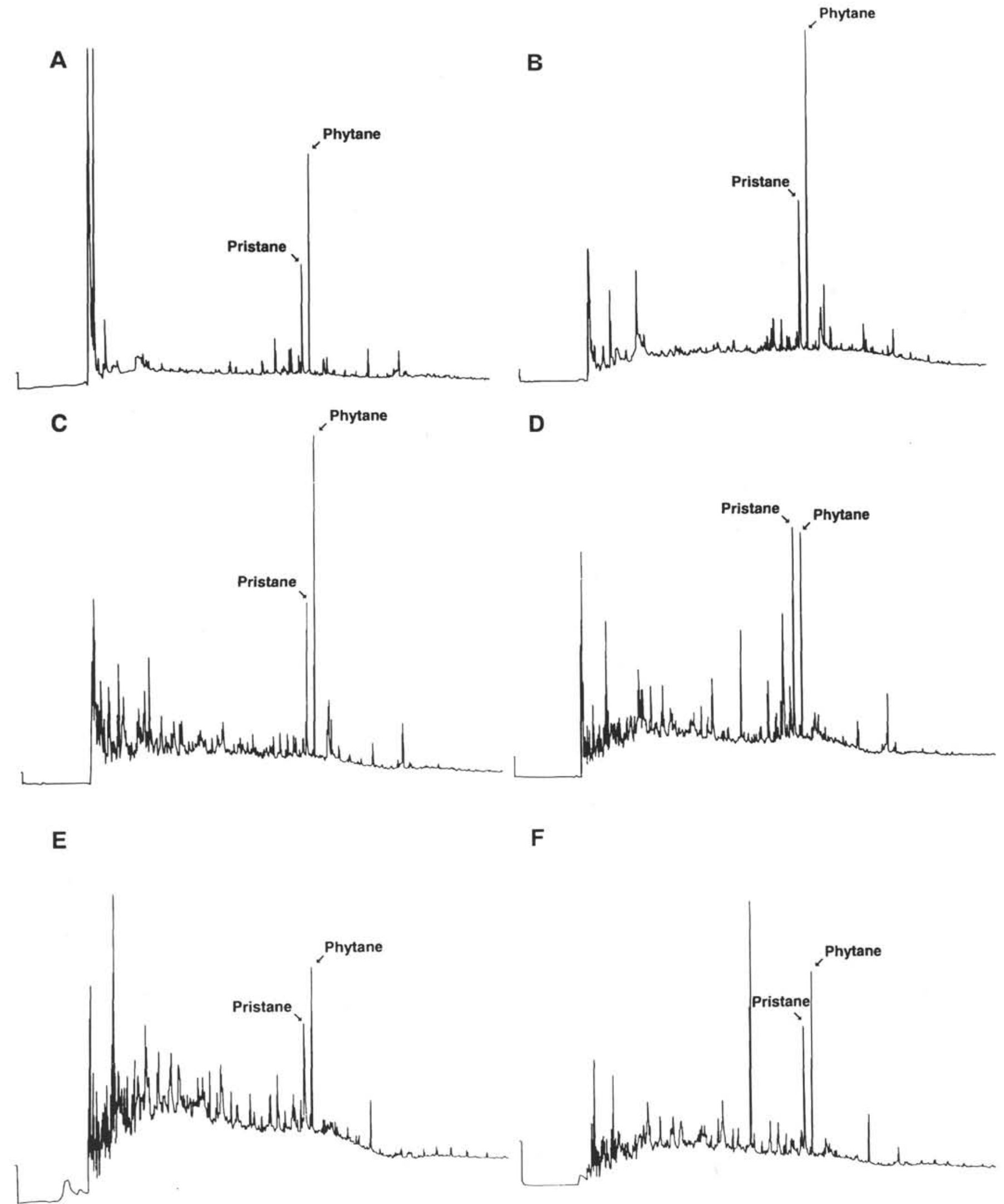

Figure 9. Gas chromatograms of thermally extracted $\mathrm{S}_{1}$ hydrocarbons. A. Sample $128-799 \mathrm{~A}-4 \mathrm{H}-6,20-25 \mathrm{~cm}$. B. Sample $128-799 \mathrm{~B}-35 \mathrm{R}-2,42-45 \mathrm{~cm}$. C. Sample 128-799B-65R-2, 130-132 cm. D. Sample 128-799B-65R-3, 42-44 cm. E. Sample 128-799B-66R-2, 53-55 cm. F. Sample 128-799B-67-1, 51-53 cm. 